\title{
36. SOME ASPECTS OF LATE CENOZOIC SEDIMENTATION IN THE BERING SEA AND NORTH PACIFIC OCEAN
}

\author{
Timothy J. Fullam, Chevron Oil Field Research Co., La Habra, California, \\ Peter R. Supko and Robert E. Boyce, Scripps Institution of Oceanography, La Jolla, California, \\ and \\ Richard W. Stewart, University of Washington, Seattle, Washington
}

\section{INTRODUCTION}

Cores recovered during Leg 19 permit a preliminary synthesis of late Cenozoic sedimentation in the Bering Sea and extreme north Pacific Ocean. In addition, the material contributes to the growing store of data aimed at deciphering the complex interactions between tectonism and sedimentation along active continental margins. Many of the deposits, until now characterized only by acoustic properties on seismic reflection profiles (Ewing et al., 1965; Scholl et al., 1968 and in press; Scholl and Hopkins, 1969; Grim and McManus, 1970; Ludwig et al., 1971b), have been directly observed and can be used in further interpretation of the acoustic data (see Scholl and Creager, this volume).

The Bering Sea includes the northernmost of the deep marginal basins associated with the dominantly convergent plate boundaries on the northern and western sides of the Pacific Ocean. It differs from other Pacific marginal basins in that the terrigenous fraction of the basin deposits is generated in high-latitude areas largely underlain by permafrost. The processes of chemical weathering, typical of temperate and tropical zones, are severely restricted, and seasonal variations in runoff and sediment contribution to the basin are extreme (Lisitsyn, 1966).

In addition to the volcanic and terrigenous components of the sediments, the high biogenic productivity of the region results in the deposition of significant (indeed, vast) quantities of siliceous microorganism remains. Although silicoflagellates and radiolarians are present, diatom frustules comprise almost all of the siliceous biogenic fraction. Carbonate horizons, some of which are composed of calcareous nannoplankton remains, also occur and indicate at least local deposition above the carbonate compensation depth.

The complex suite of sediments in the region, then, directly reflects the interaction of oceanic and continental margin sedimentation mechanisms, as well as the influence of nearby active volcanos. Overall, the Miocene to Holocene sediments of the Bering Sea are dark greenish gray hemipelagic muds with local significant quantities of intercalated sand and volcanic ash.

\section{REGIONAL SETTING AND GEOLOGY}

The lands surrounding the Bering Sea range from the vast alluvial plains of the Yukon and Kuskokwim deltas in western Alaska to the high mountainous regions of eastern Siberia. A broad, shallow shelf underlies the eastern and northern margins of the sea, bordering the Alaska lowland area on the east and the Anadyr trough to the north. The southern boundary of the Bering Sea is the Aleutian Island arc topped by numerous active and recently active volcanoes. Two deep gaps in the arc, one between Kamchatka and the Commander Islands, and the other just west of Attu in the Aleutians, connect the sea with the Pacific Ocean. A far greater water exchange with the Pacific occurs through these gaps than with the Arctic Ocean through the very shallow Bering Strait (Lisitsyn, 1966).

The deep Bering Sea is divided into three basins by submarine ridges: the Shirshov, extending due south from Cape Olyutorskiy; and the arcuate Bowers Ridge, extending north and west from the central part of the Aleutian Arc (Gershanovich, 1968; Chase et al., 1971; Kienle, 1971; Ludwig et al., 1971a). With respect to land-derived sediments, the ridges more or less isolate the three basins from each other. The largest (Aleutian) basin receives sediments mostly from the eastern shelf areas bordering Alaska and easternmost Siberia. The Kamchatka Basin, west of Shirshov Ridge, derives sediments from the Kamchatka Peninsula and southern Koryak Mountains. Sediments in the Bowers Basin are derived in part from the Aleutian and Bowers ridges and in part from spillover from the other two basins where the ridge system is partially buried (see Figure 1).

The Kuskokwim, Anadyr, and Yukon are the major rivers contributing sediment to the Bering Sea, and all three flow into the sea in the broad shelf area. The shelf probably traps much of the coarse debris carried by these rivers (Lisitsyn, 1966; Grim and McManus, 1970; Kummer and Creager, 1971); however, significant volumes of silt- and clay-sized debris also are transported and eventually reach the deep basins. During Pleistocene glacial maxima, when extensive areas of the shelf were subaerially exposed, both coarse and fine sediments, derived from the outer shelf edge, reached the deep basins to form a turbidite sequence (see for example, Ewing et al., 1965; Scholl et al., 1968).

Land areas from which the terrigenous sediments currently are being derived comprise a variety of terranes, although volcanic rocks and their derivatives predominate. The portions of Alaska drained by the Yukon and Kuskokwim rivers are underlain by a complex of Paleozoic to Mesozoic metasediments, metavolcanics, and some carbonates; immature clastic sediments of the Cretaceous Kuskokwim and Yukon-Koyukuk geosynclinal suites; and late Mesozoic and Cenozoic volcanics (Dutro and Payne, 1957; King, 1969). Small granitic plutons are scattered throughout the region. The Aleutian Ridge forming the southern margin of the Bering Sea is typical of the volcanic-plutonic arcs which characterize convergent plate boundaries in oceanic lithosphere (see for example, 


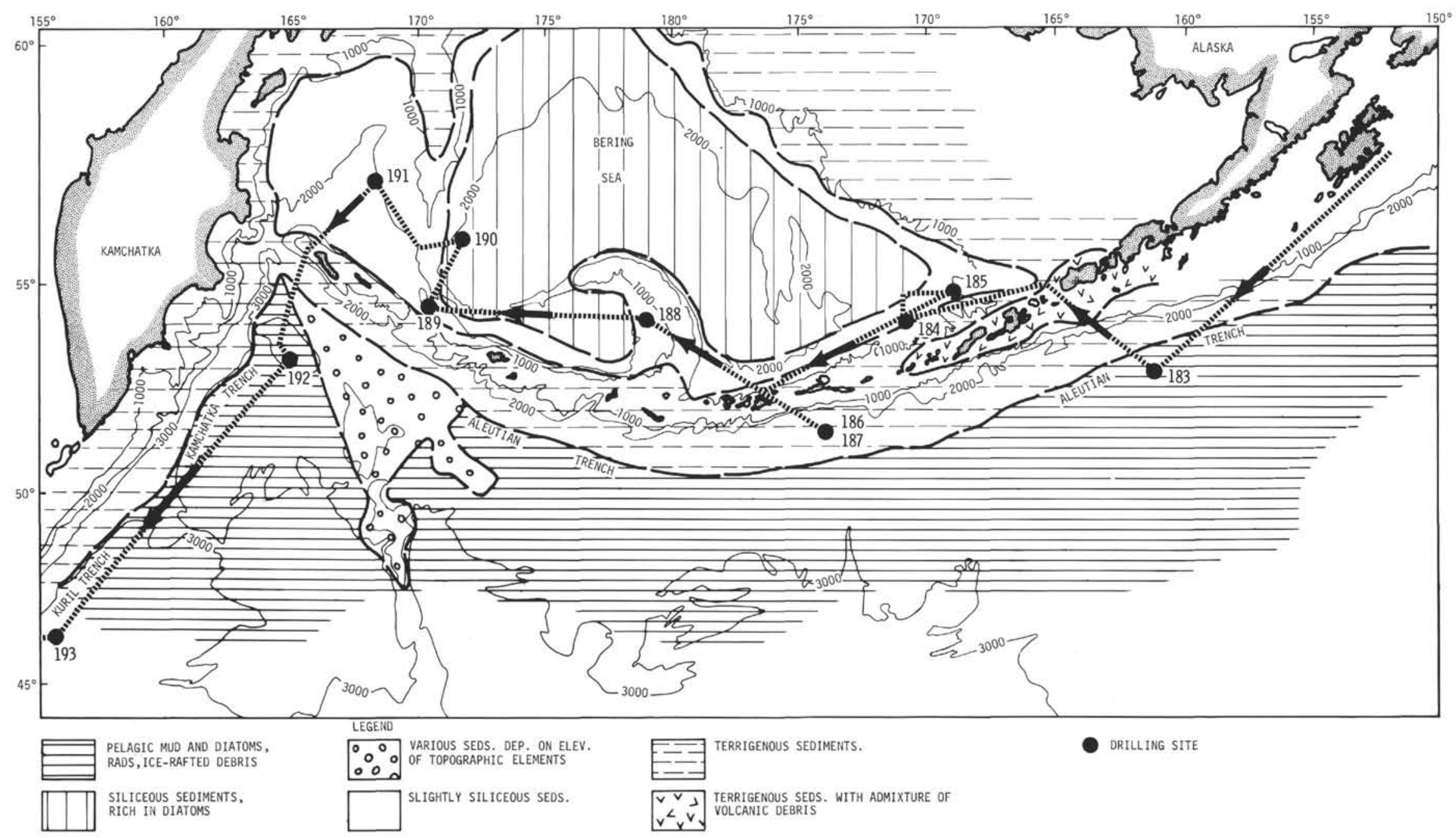

Figure 1. Sedimentary provinces of the Bering Sea and North Pacific (after Gershanovich, 1968 and Horn and others, 1970) showing location of Leg 19 drilling sites. 
Dickinson, 1971; 1972). Volcanos topping the ridge are the source for much of the abundant pyroclastic material in the sediments of the region. Marine and subaerial erosion of the ridge crest provides much coarse clastic debris shed both to the north and the south.

The western Bering Sea is bordered by the late Mesozoic and Cenozoic volcanic and associated sedimentary terranes of the Kamchatka peninsula, and by the early to late Mesozoic geosynclinal rocks of the Koryak Mountains. The Anadyr River drains an area underlain partly by portions of the Koryak Mountain complex and partly by Cretaceous and Tertiary mafic to acidic volcanics and scattered intermediate and acidic plutons (Alberta Society of Petroleum Geologists, 1960; U.S.S.R. Academy of Sciences, 1970).

\section{GENERAL CHARACTERISTICS OF BERING SEA SEDIMENTATION}

\section{Post-Middle Miocene}

Assuming an essentially fixed regional tectonic framework from late Miocene to the present (see Scholl et al., in press), a preliminary model for late Cenozoic sedimentation in the Bering Sea can be developed. Except for brief yet sometimes frequent episodes of high terrigenous or pyroclastic influx, oceanic deposition of pelagic biogenic debris has predominated. Terrigenous and volcanogenic sediments are present throughout the sampled area, but their volumetric importance varies widely. These constituents occur both as discrete beds (e.g., ash fall layers and turbidite sands) and mixed with the biogenic material as a fraction of the basic lithologies (forming, for example, silt- and clay-rich diatom ooze or diatomaceous silty clay). With information presently available, authigenic material and nonbiogenic pelagic debris cannot be distinguished, and the amount of authigenic clay in the terrigenous fraction is not known.

Although biogenic productivity in the Bering Sea undoubtedly fluctuates both areally and temporally, probably most of the variation in diatom content of the post-middle Miocene deposits results fron nonuniform dilution by terrigenous and volcanic debris. The distribution of the land-derived and pyroclastic materials is controlled in part by proximity to source areas, be they active volcanos, unconsolidated glacial or fluvial deposits, or rapidly eroding bedrock terranes. In addition, several other factors related to sediment transporting mechanisms may be important. For example, wind directions influence the distribution of volcanic ash and perhaps, to some extent, the distribution of part of the terrigenous silt and clay fraction of the diatomaceous sediments. However, oceanic circulation is the most important agent for transporting the very fine-grained terrigenous debris, and, in addition, controls the transport of rafted material. Sediments also undoubtedly move to the deep basins in turbidity currents, debris slumps. and sand falls. Deep currents capable of transporting sediments may be active as well and play some role in redistributing sediments brought to deep water by other mechanisms.

In the extreme northern portion of the Pacific basin, where it borders the Aleutian Arc, late Cenozoic sedimentation has proceeded much the same as in the Bering Sea. The regions separated from land areas by the Aleutian and Kamchatka trenches do not receive coarse turbidite or submarine slump sediments, but deposits of volcanic ash, pelagic silt and clay, and rafted debris do extend at least as far beyond the trenches as sampled. As in the Bering Sea, these mostly fine-grained sediments are laid down in varying proportions with the dominant pelagic biogenic remains.

\section{Pre-Upper (?) Miocene}

Pre-upper (?) Miocene sediments of the Bering Sea, for the most part, contain insufficient fossil remains to date them any more precisely. They are characteristically nearly barren, semi-indurated, dark greenish gray mudstones with numerous worm burrows. Conceptually, the sedimentary regime probably was similar to the present one except without the large contribution of biogenic debris. Preliminary X-ray data suggest that these older mudstones originated from alteration of volcanic debris, probably in part derived from the vigorously upbuilding Aleutian Ridge (see Scholl et al., in press).

In the North Pacific, lower Tertiary sediments were sampled at only two widely separated localities and represent quite different, though roughly time equivalent, sedimentary environments. In the present northeast Pacific, during Eocene, Oligocene, and possibly lower Miocene time, a thick section of abyssal plain turbidites was accumulating. At the same time, in what is now the northwest Pacific, deposition continued atop Meiji Guyot of a largely carbonate and mudstone sequence which had begun to accumulate in Maestrichtian time.

\section{DISCUSSION}

During the initial, shipboard descriptions of the cores, the well-dated upper Miocene and younger sediments were informally designated unit $\mathrm{A}$, and the underlying, burrowed mudstones, unit B (Figure 2). The sediments comprising the two units have been described in detail in Part I of this volume. In the following sections characteristics of the deposits will be compared and contrasted among the several drilling sites and some of the numerous remaining problems noted.

\section{Unit A}

The sites drilled in the Bering Sea and North Pacific are located in several of the modern sedimentological provinces defined by Gershanovich (1968) and Horn et al. (1970) on the basis of short cores and grab samples (Figure 1). However, the characteristics of the general sedimentary regime outlined in the previous sections can be recognized in all the areas drilled. Sites $184,185,186,187$, and 188 seem to be the most representative and simplest in terms of terrigenous and volcanic dilution complications (Figure 2). For comparison, Table 1 shows the variation in the mean diatom content (roughly determined for the non-wholly terrigenous or volcanic layers) of the unit A interval among all sites.

Except for Site 189, the sites with lower diatom contents have closer subaerially exposed source areas, more direct routes for the terrigenous debris to reach them, or, as at Sites 183 and 192, strongly reflect the increased 


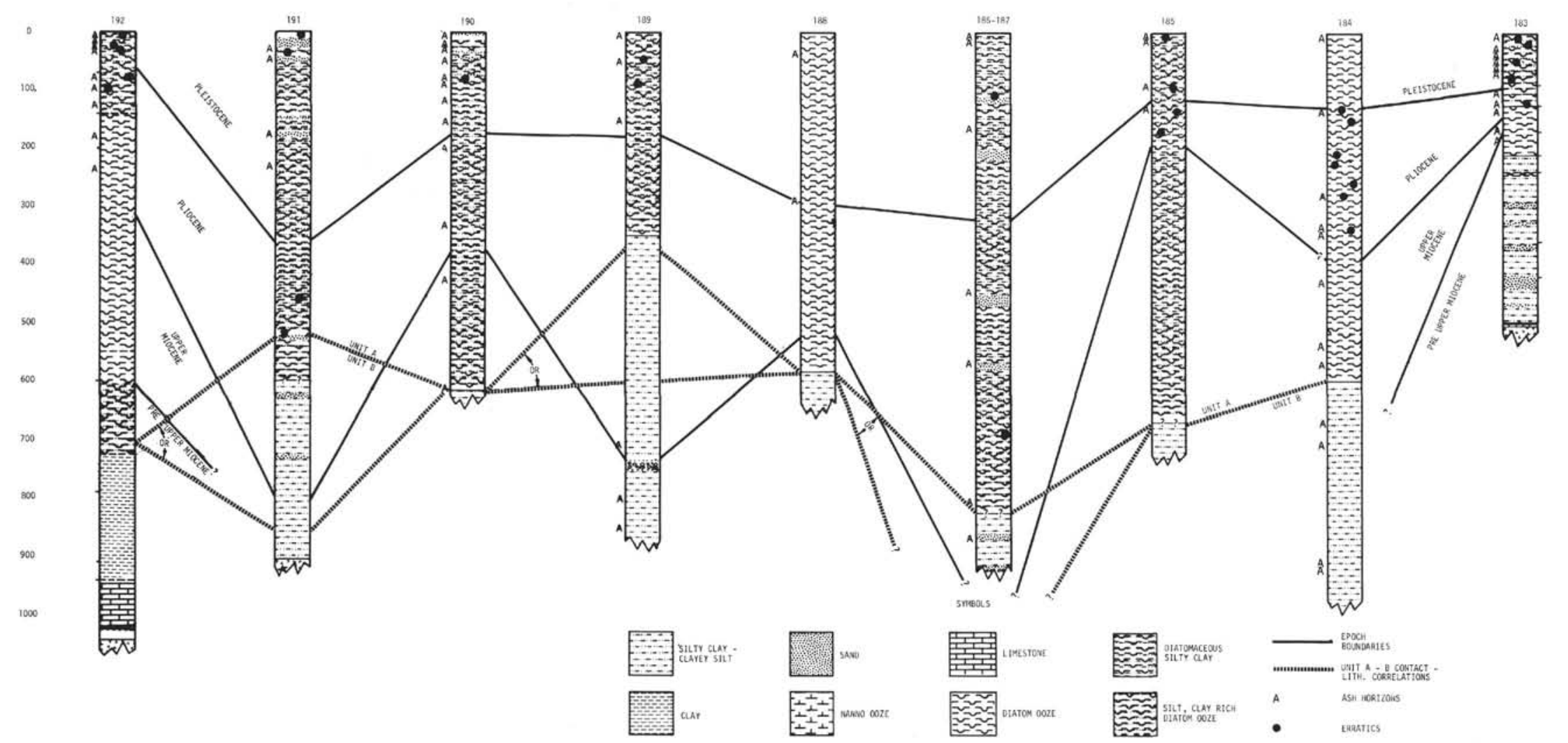

Figure 2. Correlation of North Pacific and Bering Sea sections, showing time boundaries and the contact between Units $A$ and $B$. 
TABLE 1

Variation in Basic Lithology Diatom Content

\begin{tabular}{lcl}
\hline Site & $\begin{array}{l}\text { Mean Diatom } \\
\text { Content (\%) }\end{array}$ & \multicolumn{1}{c}{ Basic Lithology } \\
\hline 183 & 60 & Silt- and clay-rich diatom ooze \\
184 & 80 & Silt- and clay-bearing diatom ooze \\
185 & 65 & Silt- and clay-rich diatom ooze \\
$186-7$ & 35 & Diatomaceous silty clay \\
188 & 75 & Silt- and clay-bearing diatom ooze \\
189 & 20 & Diatom-rich silty clay \\
190 & 40 & Diatomaceous silty clay \\
191 & 25 & Diatomaceous silty clay \\
192 & 60 & Silt- and clay-rich diatom ooze \\
\hline
\end{tabular}

terrigenous deposition of the Plio-Pleistocene. The low diatom content of the Site 189 sediments is less readily explained, because the site lies near a gap in the Aleutian Arc far from present land masses. One or a combination of three factors may be involved: a lower diatom productivity in the area, exposure of more of the eastern Aleutian Ridge during at least part of the unit A interval, and influx of suspended sediment from the Pacific through the break in the ridge. Lisitsyn (1966) states that the amount of material carried into the Bering Sea from the Pacific is much greater than the amount of solid debris derived from the surrounding land areas. Much of this suspended material presumably is deposited near the large gaps in the Aleutian Arc through which most of the Pacific water enters.

The overall low biogenic content of the diatomaceous sediments at Sites 190 and 191 indicates a high degree of dilution by terrigenous debris. In fact, the upper portion of unit $\mathrm{A}$ at both sites contains many layers nearly or completely devoid of diatoms. Some variation in diatom productivity may be involved, but more likely the diatompoor layers represent rapid influxes of terrigenous debris. On the basis of seismic reflection data (Ewing et al., 1965; Ludwig et al., 1971b) this part of the section at the two sites was interpreted to be a turbidite sequence. This conclusion was corroborated by drilling, although the section in the Aleutian Basin (Site 190) was more complex than first supposed. Whereas the Site 191 sediments include numerous size-graded sand and sandy silt layers, those at Site 190 contain only a very few coarse-grained beds, and most that do occur are thin and not apparently graded. However, the Site 190 sequence does include diatom-poor silty clay and clayey silt layers which, without microscopic examination, frequently are indistinguishable from the more diatomaceous zones. Detailed grain size analyses of some of the diatom-poor layers revealed size grading, and the layers are interpreted to be extreme distal turbidites. It is likely that some of the more diatomaceous layers are also turbidites laid down by turbidity currents which either began with diatomaceous sediments or incorporated them into the flow while traversing the basin floor.

The conceptually more typical sandy turbidites of the Kamchatka Basin (Site 191) with source areas only some $300 \mathrm{~km}$ to the west and north, are isolated from the Aleutian Basin by the north-trending Shirshov Ridge. Thus, the nearest source areas for the Site 190 turbidites, given the gradient of the basin floor, lie some 500 to $1000 \mathrm{~km}$ to the north and northeast in the Anadyr Gulf and on the Alaska shelf. In this light it is not surprising that the Site 190 turbidites are largely fine grained.

Extensive turbidite deposition began in the late Pliocene or earliest Pleistocene in the Aleutian Basin (Site 190) and somewhat earlier (lower Pliocene or uppermost Miocene?) in the Kamchatka Basin (Site 191). In general, this period of high terrigenous influx to these two basins corresponds to a time of widespread terrigenous deposition. Sediments of nearly all sites are relatively less diatomaceous in the Plio-Pleistocene part of the section. The most obvious explanation relates the increased terrigenous debris to erosion of continental shelf areas exposed during glacial maxima. In addition, increased tectonic and volcanic activity in the source terranes must not be discounted in supplying large amounts of terrigenous and volcanoclastic debris. These facts may also explain Bramlette's (1961, cited in Horn et al., 1970) observation, presumably based on shallow cores and/or grab samples, that North Pacific sediments are not diatom oozes. Beneath the PlioPleistocene terrigenous dilution zone, the upper Miocene sediments of the North Pacific are indeed nearly pure diatom oozes (see Sites 183 and 192).

In addition to the terrigenous fraction of the basic lithologies, several types of clastic debris occur as discrete interbeds or isolated units (erratics). These include rafted erratic pebbles, sands, volcanic ash beds, and carbonate layers. The origins of some of these intercalations are apparent; others are more problematical.

\section{ERRATIC PEBBLES}

Pebble-sized clasts (Figure 3) are embedded in the muds and oozes of all sites except 188. Rock types include pumice, argillite, graywacke, volcanics, and other unidentified varieties. The pumice pebbles may have been transported by wind or ocean currents without any raft, but the other types must have been rafted, probably mostly by ice. In general the occurrence of erratics coincides with the increased influx of terrigenous debris in Plio-Pleistocene time. The lack of even pumice pebbles at Site 188 remains unexplained except for the possibility that none was encountered in the discontinuous coring of the site.

\section{SANDS}

At most sites (notably $184,186,190$, and 191) the Unit A sediments include discrete beds, generally no more than a few tens of centimeters thick, of dark brown and black sand, silty sand, and sandy silt. Typically the sands seem to be most abundant in the Pleistocene section, but this may, to some extent, be an artifact of decreasing core frequency and recovery with depth. Some of the sands are size graded, especially the thicker ones (Figure 4); however, others are ungraded and some are extremely well sorted.

The composition of the sands is variable but most contain plagioclase, lithic fragments, and pyroxene as major constituents. Glass (shards?) makes up as much as 30 percent of some of the layers, particularly those laid down near the Aleutian Ridge, but in many cases the glass and other grains are extensively altered and oxide stained, making them virtually opaque and optically indistinguishable from each other. 


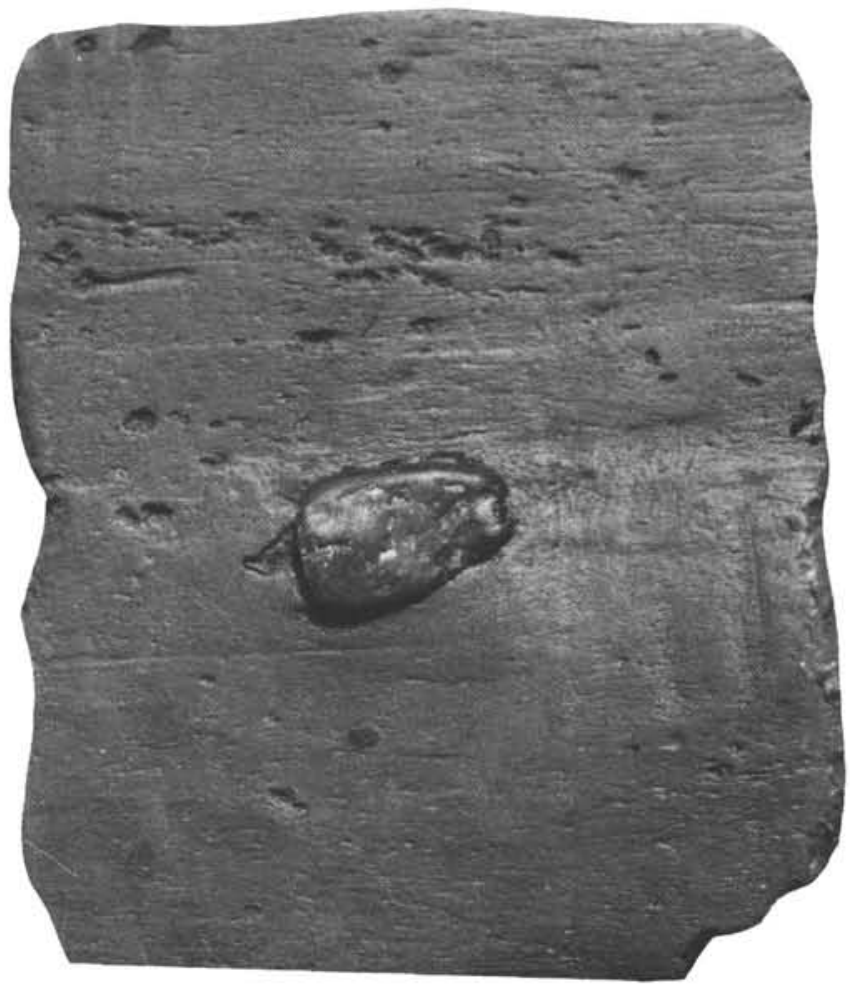

Figure 3. Rafted erratic pebble, Site 191.

The origin of the sandy layers is not entirely clear, the main difficulty being the recognition of a source and emplacement mechanism for ungraded, glassy sands or silts. The plagioclase- and pyroxene-rich composition strongly suggests ultimate derivation from mafic or intermediate volcanic rocks. One possibility is that the sands result from erosion of uplifted submarine lavas which might be expected to contain a large amount of glassy material in the matrix. Emplacement of the ungraded beds might then have been by submarine slumps or sand falls down ridge-flank canyons. Maleev (1971) describes such glassy sands as originating from pyroclastic debris reworked during the formative episode of volcanism.

The turbidite sands and silts of Sites 190 and 191 look very much like the sands from sites near the Aleutian Ridge (see discussion above). However, they contain little or no glass and, in general, have more varied compositions. The lack of glass may indicate the essential absence of unaltered submarine lavas in the source terranes of eastern Siberia and western Alaska; the varied composition simply reflects the wider variety of rocks there. In Maleev's (1971) classification, such sediments are called volcanoterrigenous, being derived from older volcanic rocks.

\section{VOLCANIC ASH}

Of universal occurrence in the unit $\mathrm{A}$ sediments are vitric volcanic ash layers, composed of 50 to 100 percent glass shards. Most of the ash horizons are a maximum of $10 \mathrm{~cm}$ thick, although several much thicker ones do occur (e.g., $190-8-2,50 \mathrm{~cm}$ thick; $183-12-1,2,80 \mathrm{~cm}$ thick; 186-9-1, 2, 3 , nearly $4 \mathrm{~m}$ thick). As with the sand layers described

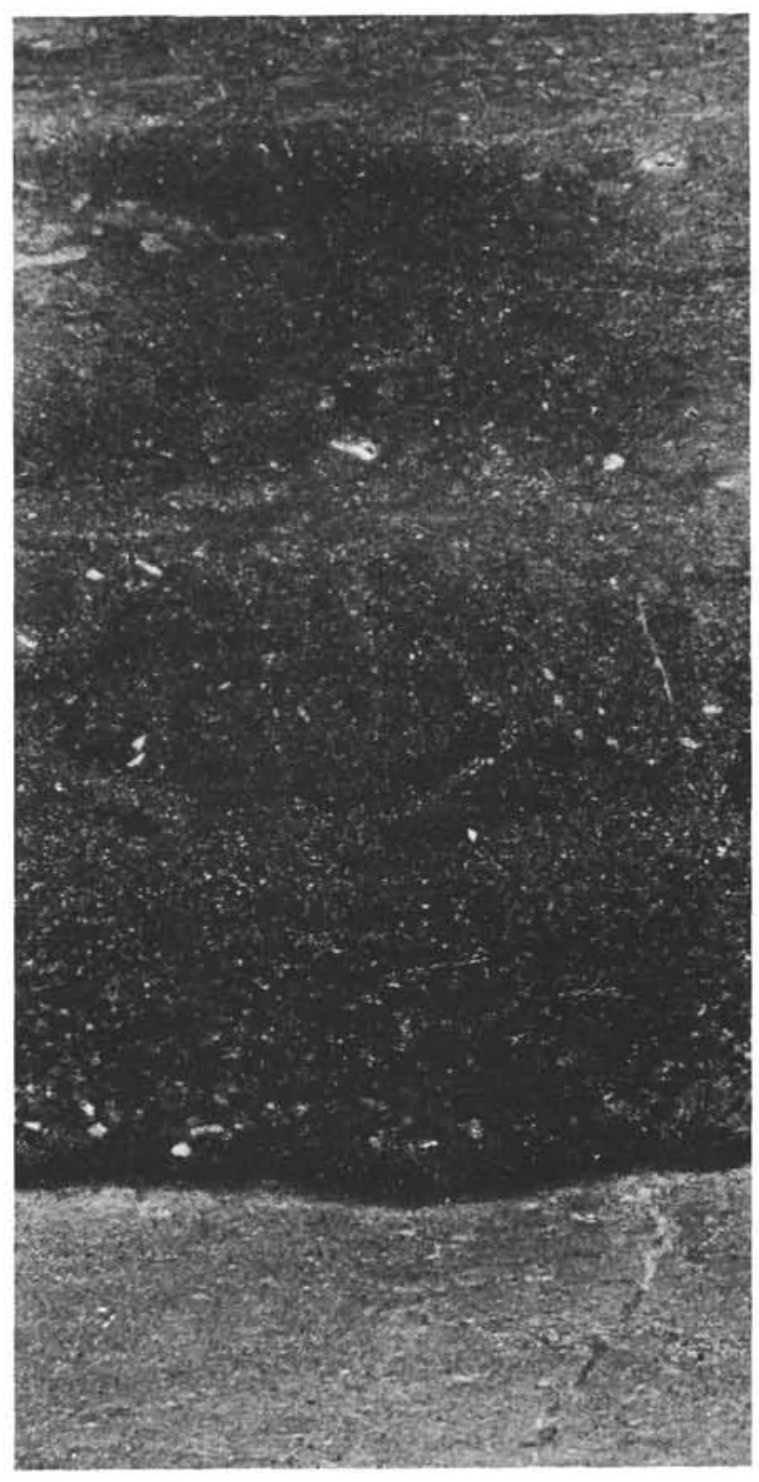

Figure 4. Size graded sand layer, Site 184.

above, the ashes appear to be most numerous in the Pleistocene section, probably reflecting the growth of the large Quaternary stratovolcanoes atop the Aleutian Ridge and Kamchatka volcanic arc.

The ash horizons are of two general types: mostly light gray to light brown layers consisting of virtually 100 percent glass shards, and dark colored "crystal" ashes containing a significant portion of mineral grains, mostly plagioclase, pyroxene, and lithic fragments, in addition to the glass. At a few sites (notably 184 and 185 which are close to source volcanoes) some of the light ash layers are composed of pumice lapilli. These sites also contain the most abundant isolated pumice pebbles (see discussion of erratics). The dark, so-called crystal ashes may have an origin similar to that suggested for the glassy sands. Alternatively, they could result from some process of mixing of vitric ash and eroded rock debris or be entirely pyroclastic resulting from ejections of partially crystallized magma. 


\section{CARBONATES}

Except for minor occurrences of pods of nannofossil ooze and carbonate-cemented diatomaceous zones, unit A carbonates are restricted to the lower part of the interval. The variation in carbonate content of the calcareous intervals results in zones ranging from slightly calcareous silty clays, to calcite-cemented diatom oozes, ashes and sands, to pure or nearly pure limestones. Although carbonate horizons were encountered in unit A at all sites, they are thickest and most numerous at the two Umnak Plateau sites (184 and 185) which presently have the shallowest water depths of any site. Presumably the primary carbonate zones represent at least local upward excursions of the carbonate compensation depth and/or brief increases in productivity of any calcareous organisms involved in forming the layers. (For a more complete discussion of carbonates encountered in Leg 19 coring, see the Site Report chapters in this volume.)

\section{Unit B}

In the Bering Sea and extreme northwest Pacific a monotonous sequence of dark greenish gray mudstones underlies unit A. Informally designated unit B (Figure 2), these older sediments are distinguished from the richly fossiliferous unit A by having a greater degree of induration, a virtual absence of diatoms, and an abundance of burrow structures and mottling. No age-diagnostic fossils were recovered in relatively limited sampling of unit B, so conclusions regarding its origin and age are tentative.

Sediments well established as belonging to unit B were recovered from Sites $184,188,189,190$, and possibly 191 in the Bering Sea and from Sites 192 and possibly 186 in the North Pacific (Table 2). The Site 185 hole penetrated an apparent transition zone between the two units. At other sites, where the boundary was actually cored, the contact between units A and B is relatively abrupt.

At Site 189 the diatom content decreases markedly between Cores 7 and 8 ( 305 to $362 \mathrm{~m}$ below bottom), and sediments recovered between 362 meters and about 600 meters below bottom (Cores 8,9 , and 10) bear a superficial resemblance to unit $\mathrm{B}$. However, these cores still contain sufficient diatoms to date them with certainty. If they are unit B, the unit A-B contact at Site 189 is much higher in the section and occurs at a later time (Table 2) than at most other sites. X-ray data (Table 3) show a change in mineralogy between Cores 10 and 11 (550 to $640 \mathrm{~m}$ below bottom). This favors a unit B to A transition in that interval. From Core 11 to the bottom of the hole, typical unit B sediments were recovered. The exact A-B boundary is moot. It thus may be in the Pliocene or near the Miocene-Pliocene boundary.

The location of the unit A-B contact at Site 191 is even less clear. The change from unit A to unit B type sediments occurs between Cores 12 and 13 (527 to $620 \mathrm{~m}$ below bottom); however, a limited upper Miocene (?) diatom flora occurs in Core 14 (723 to $732 \mathrm{~m})$. There are several implications of these facts: (a) Unit B may be at least locally slightly diatomaceous in its upper part. In this case the contact might arbitrarily be placed at 600 meters. (b) The contact between units A and B may lie between
Core $14(732 \mathrm{~m})$ and the basalt basement at 905 meters, an interval in which no cores were taken. (c) Unit B may be absent at Site 191. In view of the typical unit B lithologies recovered in Cores 13 and 14 and of the similar situation at Site 189, the first alternative seems most reasonable. However, if this is correct, then the upper portion of unit A is much thinner than at other sites (Figure 2). Also if this is correct, A-B transition is in the Pliocene. In case (d) the transition would be in the Miocene.

The contact at Site 186 on the Aleutian Terrace poses a similar question. Although the diatom content is sharply reduced and typical unit B lithologies are encountered below Core 26 ( $814 \mathrm{~m}$ below bottom), the sediments are still diatom bearing. Thus, the Core 27 and 28 sediments could reflect a situation similar to that represented by Cores 8,9 , and 10 at Site 189 , placing the top of unit B somewhere below 926 meters below bottom. Alternatively, they could be roughly correlative with Core 13 and 14 sediments at Site 191 and represent a locally diatombearing upper part of unit B.

Summarizing the above, we may state that, while lithologic complexities at Sites 186, 187, 189, and 191 make exact unit boundaries less than clear, the transition from unit B to unit A lithology was roughly synchronous and was sometime in upper Miocene time.

Unit B deposition apparently ceased somewhat earlier in the northwest Pacific than in the Bering Sea. At Site 192 atop Meiji Guyot, diatomaceous sediments (unit A) began to accumulate in middle Miocene time (between Cores 26 and 27,718 to $746 \mathrm{~m}$ below bottom) (Table 2, Figure 2), perhaps indicating that suitable conditions for a diatom bloom were first achieved south of the Aleutian Ridge.

With the limited X-ray data presently available (Table 3), little can be said about the overall composition of unit B. However, the occurrence of cristobalite, montmorillonite, and zeolites clinoptilolite and phillipsite is consistent with an origin from alteration of volcanic debris. Indurated vitric ash or tuff beds are intercalated with other unit B sediments at Sites 184 and 189 and provide evidence for active volcanism during unit B time. Like unit A, the older unit undoubtedly was deposited in a locally variable sedimentary basin which was receiving sediments from a variety of source terranes. Thus, the differences in X-ray mineralogy between Sites 188 and 189 (Table 3) are not surprising.

TABLE 2

Depth and Minimum Age of Unit A-Unit B Contact

\begin{tabular}{lll}
\hline Site & $\begin{array}{c}\text { Subbottom Depth } \\
\text { to Top Unit B (m) }\end{array}$ & $\begin{array}{c}\text { Age of Oldest } \\
\text { Overlying Sediment }\end{array}$ \\
\hline 184 & 603 & U. Mio \\
185 & $670-728+$ (Transition) & U. Mio. \\
186 & $825 \pm$ or $926+?$ & U. Mio. or Plio. \\
188 & 582 & U. Mio. \\
189 & $600 \pm(380 \pm ?)$ & U. Mio. (Plio.?) \\
190 & 615 & U. Mio. \\
191 & $520 \pm$ or $900+?$ & U. Mio or Plio. \\
192 & $725 \pm$ & M. Mio. \\
\hline
\end{tabular}


TABLE 3

X-Ray Mineralogy Data

\begin{tabular}{|c|c|c|c|c|c|c|c|c|c|c|c|c|c|c|c|c|c|c|c|c|c|c|c|c|c|}
\hline \multirow[b]{2}{*}{ Mineralogy } & \multicolumn{9}{|c|}{ Site 188} & \multicolumn{13}{|c|}{ Site 189} & \multicolumn{3}{|c|}{ Site 190} \\
\hline & $\begin{array}{c}6-3 \\
22-24 \\
\end{array}$ & $\begin{array}{c}6-3 \\
65-66 \\
\end{array}$ & $\begin{array}{c}9-3 \\
96-97\end{array}$ & $\begin{array}{c}12-1 \\
115-120\end{array}$ & $\begin{array}{c}14-1 \\
130-135\end{array}$ & $\begin{array}{c}15-2 \\
120-122\end{array}$ & $\begin{array}{l}17-1 \\
40-42\end{array}$ & $\begin{array}{l}17-1 \\
80-82 \\
\end{array}$ & $\begin{array}{l}17-1 \\
90-92 \\
\end{array}$ & $\begin{array}{c}6-2 \\
18-20 \\
\end{array}$ & $\begin{array}{l}7-2 \\
6-8 \\
\end{array}$ & $\begin{array}{c}8-1 \\
107-109\end{array}$ & $\begin{array}{l}10-1 \\
59-61\end{array}$ & $\begin{array}{l}11-3 \\
75-77\end{array}$ & $\begin{array}{l}12-2 \\
50-52\end{array}$ & $\begin{array}{l}12-2 \\
83-85\end{array}$ & $\begin{array}{l}13-3 \\
55-57 \\
\end{array}$ & $\begin{array}{c}14-3 \\
140-142\end{array}$ & $\begin{array}{l}14.4 \\
78-80 \\
\end{array}$ & $\begin{array}{c}14-4 \\
148-150\end{array}$ & $\begin{array}{l}15-1 \\
94-96 \\
\end{array}$ & $\begin{array}{l}20-2 \\
68-70 \\
\end{array}$ & $\begin{array}{c}7 \cdot 2 \\
55-57 \\
\end{array}$ & $\begin{array}{c}9-2 \\
33-35 \\
\end{array}$ & $\begin{array}{c}15-1 \\
126-128 \\
\end{array}$ \\
\hline $\begin{array}{l}\text { Amorphous } \\
\text { silica }\end{array}$ & 96.9 & 84.4 & 96.0 & 79.7 & 84.3 & 92.7 & 41.4 & 87.1 & 83.8 & 70.3 & 71.8 & 63.6 & 64.6 & 46.8 & 38.1 & 69.1 & 48.2 & 46.6 & 43.6 & $35.6 ?$ & 51.5 & 42.8 & 79.9 & 64.2 & 97.6 \\
\hline Calcite & 0.4 & & & & & 0.1 & & & & & & & & & & & & & & $(25.0) ?$ & & & & & \\
\hline Dolomite & & & & & & & 55.4 & & & & & & & & & & & & & & & & & & \\
\hline Quartz & 0.5 & 4.1 & 0.7 & 4.8 & 3.1 & 1.3 & 1.1 & 0.5 & 1.0 & 9.6 & 9.2 & 12.3 & 12.9 & 33.0 & 45.6 & 3.4 & 27.7 & 24.6 & 13.0 & 8.6 & 28.0 & 40.8 & 7.3 & 12.4 & 0.4 \\
\hline Cristobalite & & & & & & & & 11.3 & 12.1 & & & & $\operatorname{Tr}$ & & & & & & & & & & & & \\
\hline Plagioclase & 1.0 & 5.1 & 1.8 & 6.9 & 6.2 & 4.0 & 2.1 & 0.6 & 1.5 & 7.0 & 9.3 & 7.7 & 5.1 & 7.9 & 8.1 & 9.5 & 11.3 & 17.1 & 20.8 & 23.8 & 8.7 & 9.5 & 5.8 & 5.2 & 0.8 \\
\hline Mica & 0.5 & 3.9 & 0.6 & 3.8 & 1.2 & 0.4 & & & 0.4 & 5.9 & 3.5 & 10.9 & 14.2 & 4.0 & 4.5 & 1.6 & 5.1 & 6.5 & 5.8 & $1.8 ?$ & 7.4 & 4.6 & 9.1 & 14.1 & 1.1 \\
\hline Chlorite & 0.4 & 1.0 & 0.6 & 1.7 & 0.9 & 0.7 & & 0.1 & 0.2 & 1.3 & 1.6 & 2.2 & 2.8 & 1.9 & 1.9 & 0.6 & 2.8 & 5.1 & 16.9 & 5.2 & 2.9 & 2.3 & 2.0 & 3.4 & 0.2 \\
\hline Montmorillonite & & 0.6 & & 2.0 & 2.9 & 0.5 & & 0.2 & 0.5 & 5.3 & 3.8 & 2.3 & 0.5 & 3.5 & 1.8 & 12.8 & 4.0 & & & & 0.9 & & 0.8 & 0.6 & \\
\hline Clinoptilolite & & & & & & 0.2 & & & 0.2 & 0.6 & 0.9 & 0.4 & & 2.3 & 2.4 & 2.4 & & & & & & & & & \\
\hline Pyrite & 0.2 & 0.7 & 0.2 & 0.8 & 1.2 & 0.4 & & 0.2 & 0.3 & & & & & 0.7 & & 0.5 & 1.0 & & & & 0.6 & & & & \\
\hline Amphibole & & 0.3 & 0.2 & 0.3 & & & & & & & & & & & & & & & & & & & & & \\
\hline Halite & 0.2 & & & & 0.3 & & & & & & & & & & & & & & & & & & & & \\
\hline \multirow[b]{2}{*}{ Lithologya } & \multicolumn{6}{|c|}{ Unit A } & \multicolumn{3}{|c|}{ Unit B } & \multicolumn{4}{|c|}{ Unit A } & \multicolumn{8}{|c|}{ Unit B } & & \multicolumn{3}{|c|}{ Unit A } \\
\hline & 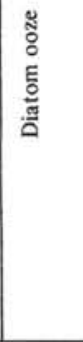 & 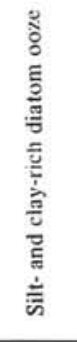 & 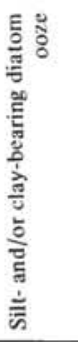 & 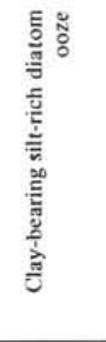 & 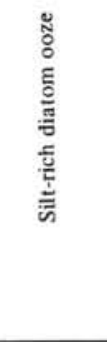 & 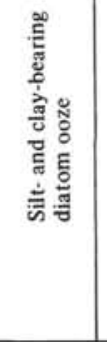 & $\begin{array}{l}\frac{\mathscr{2}}{\tilde{E}} \\
\frac{0}{0} \\
\frac{0}{0}\end{array}$ & 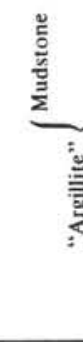 & & 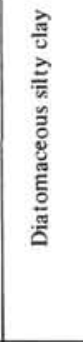 & 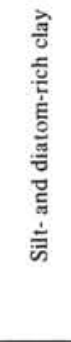 & 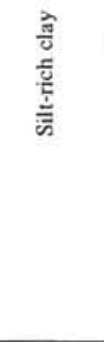 & बह & 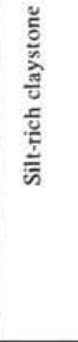 & 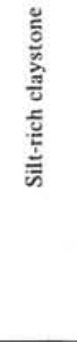 & 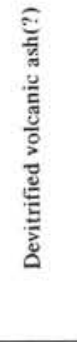 & 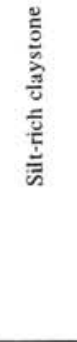 & 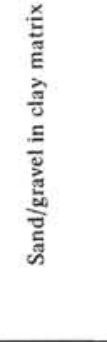 & 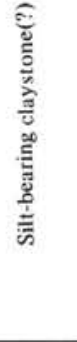 & 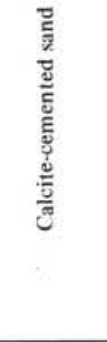 & 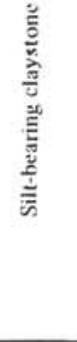 & 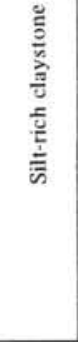 & 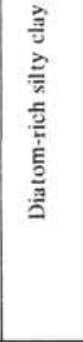 & 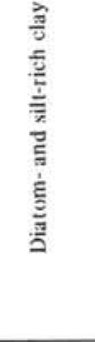 & 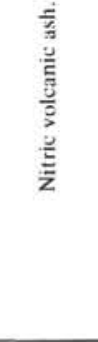 \\
\hline
\end{tabular}




\section{STRUCTURES}

Unit B sediments are characterized by extensive backfilled burrow structures (Figure 5). In most cases they parallel the bedding and, in fact, appear to be planar features rather than single, backfilled tubes. It may be that the occurrence of discrete burrows may indicate a relatively low degree of biologic activity within the sediments. Burrows do transect bedding planes in some places and occasionally are seen to terminate at a pyrite (or marcasite?) nodule.

Prominent, although often irregular and lensy, bedding also distinguishes the older unit. At Sites 186 and 189 near the Aleutian Ridge the bedding dips as much as 30 degrees, and at Site 189 tension fractures have developed normal to the bedding planes. These fractures (Figure 6) probably were formed in the semiconsolidated sediments in response either to slumping on the flanks of an original high or to tension in near crestal deposits on an active uplift or arch.

\section{CONCLUSION}

\section{The Unit A-Unit B Transition}

It seems remarkable that the transition from unit B to unit A occurs at such a consistent subbottom depth over such a wide area (see Table 2). The implication of basically undisturbed sedimentation from upper Miocene-lower Pliocene time to the present is supported by the basic uniformity of unit A sediments among the various sites. In general the top of unit B is deeper in the sediment column at sites where there has been a high degree of terrigenous

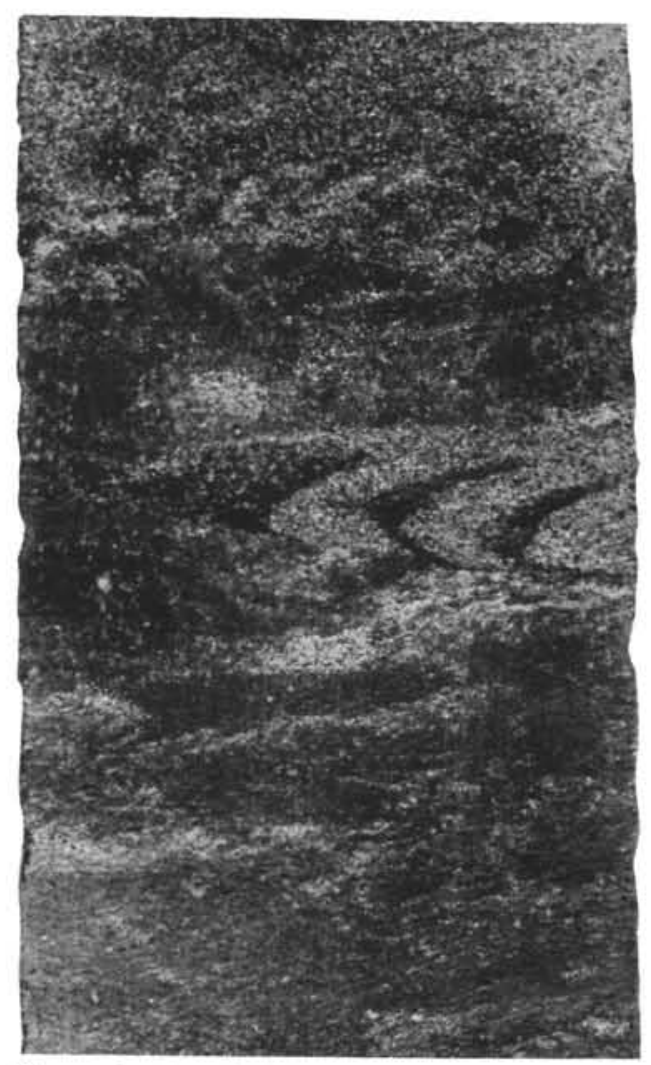

Figure 5. Backfilled burrow, Unit B, Site 184. sedimentation during unit A time (for example, Sites 185 and 186). The contact at Site 191 is not depressed, even though unit A contains much terrigenous debris, but as previously noted the lower part of that unit may be anomalously thin.

The occurrence of partially dissolved diatoms in the upper part of unit B and/or the lower part of unit A leads to some speculation that unit B is merely an older, diagenetically altered facies of unit A type sediments. This is unlikely, however, in light of the distinctive burrow structures of unit B. Such features occur only sporadically in basal unit A deposits. Nevertheless, some diagenetic processes are active in the vicinity of the contact, causing dissolution of the diatoms and some pyritization. At Site 185 natural gas is associated with the contact.

The transition from unit B to unit A most likely represents a marked change in sedimentation in the area. The change may have begun relatively slowly, and somewhat earlier-south of the Aleutian Ridge, in late unit B time. Subsequent diagenetic alteration has at least locally obliterated the diatoms in unit B and emphasized the abruptness of the contact with the overlying sediments. In any event the changing sedimentary environment must have

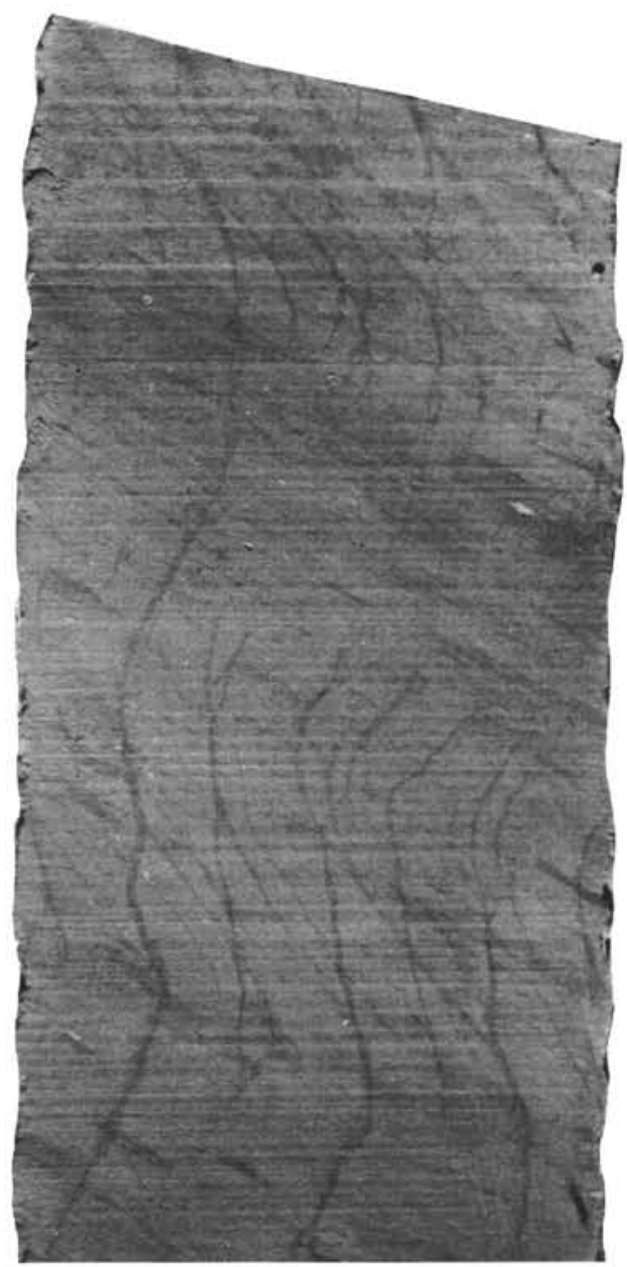

Figure 6. Tension fractures, Unit B, Site 189-13-2 $(115-127 \mathrm{~cm})$. 
involved the development at some point in middle or late Miocene time of oceanic conditions which allowed a massive expansion of diatom productivity. These conditions basically have prevailed to the present.

\section{REFERENCES}

Alberta Society of Petroleum Geologists, 1960. Geological Map of the Arctic. First Intern. Sympo. Arctic Geol. Calgary.

Chase, T. E., and Menard, H. W. and Mammerick x, J., 1971. Topography of the North Pacific. Geol. Data Center, Scripps Inst. Oceanogr., Inst. Marine Res., La Jolla, California.

Dickinson, W. R., 1971. Plate tectonic models of geosynclines. Earth Planet. Sci. Letters. 10, 165.

1972. Evidence for plate-tectonic regimes in the rock record. Am. J. Sci., 272, 551.

Dutro, J. T., and Payne, T. G., 1957. Geologic map of Alaska. U.S. Geol. Surv. Scale 1:2,500,000.

Ewing, M., Ludwig, W. J. and Ewing, J., 1965. Oceanic structural history of the Bering Sea. J. Geophys. Res., 70, 4593 .

Gershanovich, D. E., 1968. New data on geomorphology and recent sediments of the Bering Sea and the Gulf of Alaska. Marine Geol. 6, 281.

Grim, M. S. and McManus, D. A., 1970. A shallow seismic-profiling survey of the northern Bering Sea. Marine Geol. 8, 293.

Horn, D. R., Horn, B. M. and Delach, M. N., 1970. Sedimentary provinces of the North Pacific. In Geological Investigations of the North Pacific, J. D. Hays (Ed.). Geol. Soc. Am. Mem. 126.
Kienle, J., 1971. Gravity and magnetic measurements over Bowers Ridge and Shirshov Ridge, Bering Sea. J. Geophys. Res. 76, 7138.

King, P. B., 1969. Tectonic map of North America. U.S. Geol. Surv. Scale 1:5,000,000.

Kummer, J. T. and Creager, J. S., 1971. Marine geology and Cenozoic history of the Gulf of Anadyr. Marine Geol. $10,257$.

Lisitsyn, A. P., 1966. Recent sedimentation in the Bering Sea. Israel Program for Scientific Translations, Jerusalem, $1969.614 \mathrm{p}$.

Ludwig, W. J., Murauchi, S., Den, N., Ewing, M., Hotta, H., Houtz, R. E., Yoshii, T., Asanuma, T., Hagiwara, K., Sata, T. and Ando, S., 1971a. Structure of Bowers Ridge, Bering Sea. J. Geophys. Res. 76, 6350.

Ludwig, W. J., Houtz, R. E., and Ewing, M., 1971b. Sediment distribution in the Bering Sea: Bowers Ridge, Shirshov Ridge, and enclosed basins. J. Geophys. Res. 76, 6367.

Maleev, E. F., 1971. Classification of certain types of volcanogenic-sedimentary rocks. Lithol. Min. Res. 6 (5), 622. Trans. Publ. Aug. 1972.

Scholl, D. W. and Hopkins, D. M., 1969. Newly discovered Cenozoic basins, Bering Sea shelf, Alaska. Bull. Am. Assoc. Petrol. Geologists. 53, 2067.

Scholl, D. W., Buffington, E. C. and Hopkins, D. M., 1968. Geologic history of the continental margin of North America in the Bering Sea. Marine Geol. 6, 297.

Scholl, D. W., Buffington, E. C. and Marlow, M. S., in press. Plate tectonics and the structural evolution of the Aleutian-Bering Sea region: solutions and complications. Geol. Soc. Am. Special Paper.

U.S.S.R. Academy of Sciences, Geological Institute and Institute of Oceanology, 1970. Tectonic Map of the Pacific Segment of the Earth. Scale 1:10,000,000. Moscow. 